\title{
MASLAHAH BASED MEASUREMENT ON INDONESIA ISLAMIC BANKS
}

\author{
Aam S. Rusydiana ${ }^{1 *}$, Hendri Tanjung ${ }^{2 *}$, Lina Marlina ${ }^{3 *}$
}

\begin{abstract}
* Affiliation:
${ }^{1}$ Sharia Economic Applied Research \& Training (SMART) Indonesia email: aamsmart@gmail.com
\end{abstract}

${ }^{2}$ Ibn Khaldun University, Indonesia

email:

hendri.tanjung@gmail.com

${ }^{3}$ Siliwangi University

Tasikmalaya, Indonesia email:

linamarlina@unsil.ac.id

\begin{abstract}
:
Every single effort or process taken by Islamic bank to maximize output should also uphold Islamic values, so that maqashid sharia (maslahah-sharia objectives) would be authomatically achieved. There were some research conducted to measure Islamic bank performance using maqashid sharia framework. However, these studies were not explicitly addressing the issue of cost-saving strategies within the framework of efficiency measurement. It is therefore this paper aims to have efficiency and maslahah measurement in one assessment framework that is maslahah-eficiency quadrant (MEQ). There are three aspects measurement of maslahah, namely education, justice, and welfare as maqashid sharia index (MSI). Hence, in order to measure efficiency level of Islamic Banking Industry especially Sharia Business Unit, this study use Data Envelopment Analysis (DEA) method and employ Banxia Frontier Analyst 3.1 for data analysis. Within the MEQ framework, the study revealed that Permata, CIMB, BTN, DKI, Jambi, and Kalbar are excellent since both are within the first quadrant. Whereas Maybank, NISP, Sinarmas, Sumbar, and Sulselbar are considered good at the second quadrant; Danamon, Jatim, Sumut, Riau\&Kepri, Kalsel, and Kaltim are fair at the third; and DIY, Jateng, and NTB are poor at the fourth sequentially. It is urge for Islamic bank that are in low level of MSI to have a critical policy to keep in line with the five factor of maqashid sharia apart of having efficiency in order to reach maslahah.
\end{abstract}

keywords: Maslahah-Efficiency Quadrant (MEQ), Maqashid Sharia index (MSI), DEA, Islamic Bank

\section{INTRODUCTION}

The Development of Islamic Banking Industry in Indonesia relatively shows a good tendency, although seemed too slowly. Islamic Banking Statistic Data on December 2018 shows that the number of Islamic Banking in Indonesia has been reached 13 of Islamic Banking, 23 of Islamic Business Units, and 163 of Islamic Financing Bank (BPRS) with 2,301 of total office channeling in Indonesia (Financial Service Authority [OJK], 2018). Regarding to Global Islamic Finance Report (2018), 
Islamic Financial Industry in Indonesia has been in the top seventh of the world after Iran, Malaysia, Arab Saudi, UAE, Kuwait and Bahrain. Index score of Islamic Financial Industry in Indonesia 2018 is 24.7 in the scale of 100 and ranked $7^{\text {th }}$ in the world.

Regardless of the data, target in 2017 which was formulated by Bank Indonesia to achieve $5 \%$ of market share was not satisfied. The growth occurs in Islamic Bank was not much better than the growth of market share it self. Market share target of Islamic Bank in 2018 that was not sufficient is become a phenomenon to evaluate the performance of whole Islamic Banking efficiency in Indonesia. There are some obstacles such as competitions, conversion process from Islamic Business Unit into Islamic Banking, and then it would be so many investment values to be expended. As a result, inefficiency would be the great obstacles in head to head to conventional bank.

Berger, et al (1993) in Komaryatin (2006) explained that if the change of financial structures is occurred rapidly, then it is important to identify the cost efficiency and income. In the end of 2018, Islamic Banking has increased in asset and financing, so it's needed an investigation (research) related to the efficiency of Islamic Bank in Indonesia. This is all cause, great value of asset or financing haven't been showing great efficiency yet, so to achive maximum efficiency score, the financial proportion in the bank must be sufficient with their need.

It is true that necessary for sharia banks to maintain their efficiency, but not sufficient. A sound financial ratio should be reflected in the process of achieving it. The target to optimize the efficiency level does not then justify any means to achieve it. In fact, the achievements of company profits with sound financial ratios are not proportionally followed by the employee quality. The interest of the shareholders is achieved by the high return rate, but the main input is from the financial instrument that contains riba. It is therefore, the effort to measure the performance of sharia banks only from the financial ratio alone is not enough. Another thing that is also very fundamental apart from having efficiency level is in line with the achievement of sharia objectives (maqashid shariah). Having different nature of values and variety of products, any efforts to conduct assessment and supervision between sharia banks and conventional banks should be different. Therefore some papers that try to compare between sharia with conventional bank only by seeing its financial ratio just become less precise.

Several efforts to present the performance assessment of sharia banks have been done based on maqashid sharia. These studies include, among others, Muhammed et al., 2008; Muhammed and Taib, 2009; Kuppusamy, Saleha and Samudhram, 2010; Antonio et al., 2012; Bedoui and Mansour, 2013; Jazil and Syahruddin, 2013; Muayyad and Esya, 2016, and Saoqi, 2017. However, these studies were not explicitly addressing the issue of cost-saving strategies within the framework of efficiency measurement. Efficiency is a process of how firm utilizes their resources (inputs) to produce the desired products or services (outputs). It will indicate the success of the firm. If the firm gains a high level of efficiency, it indicates that the firm performs well in the operating condition and is able to manage all the resources. Eventually, this will lead to further developments such as improvement in the products and services, higher shareholder's value and higher economic growth if the funds are invested into more profitable ventures. 
Hence, comparing Islamic and conventional bank solely on the efficiency measurement would leads to misleading conclusion since there are having different set of values and products. Every single effort or process taken by sharia bank to maximize output should also uphold Islamic values, so that maqashid sharia (maslahah/sharia objectives) would be authomatically achieved. It is therefore this paper aims to have efficiency and maslahah measurement in one assessment framework that is maslahah-eficiency quadrant (MEQ).

The remainder of the paper is organized as follows. Section 2 reviews the literatures regarding Islamic bank evaluation within the framework of efficiency and maqashid sharia. Section 3 describes methodology, particularly maslahah-eficiency quadrant (MEQ) which is employed in the study. Result and discussion are presented in section 4. Finally, section 5 contains conclution and recommendation.

\section{LITERATURE REVIEW}

\section{The Efficiency Concept}

Despite of market condition under perfect or unperfect competition, bank has to reach its level of efficiency in order to succeed and make a profit; those who do not will fail and be forced to exit the market. Efficiency is important for business entity. Efficiency concept is defined as doing something correctly (doing the thing right). Efficiency concept usually associated with the way of corporate in achieve its goals. Therefore, efficiency concept usually measured by using cost aspect as input and profit as output. Business entities are also trying to minimize cost until the minimum level to produce maximum output (profit) (Ali, 2010).

Nopirin (1997) explained that efficiency is the absence of waste cost. Rinald (1981) in Komaryatin (2006) stated that efficiency is the ratio of output and input, which is associated to maximum output achievement and some inputs. It means that if rasio of ouput and input are increased, means that the higher efficiency is achieved, and then we can conclude that efficiency is using of best input to produce output. Efficiency concept is coming from micro economic concept, production theory. Production theory tried to maximize profit or minimize cost from producer view. Production theory explained the production frontier curve, which describe the correlation of input and output from production process. Production frontier curve represents the maximum output level from each input using, and also represent the use of technology from a producer or industry (Ascarya and Yumanita, 2007).

Several efforts to present the performance assessment of Islamic banks have been done within the efficiency framework. The study of Islamic bank within efficiency framework could be classified into two main groups; (1) the efficiency of Islamic bank, and (2) the comparison of efficiency between Islamic bank and conventional. The first group studies, include among others were Bader et al., 2007; Brown \& Skully, 2004; Hassan, 2006; Yudistira, 2003; Sufian, 2006; Ascarya \& Yumanita, 2006). While the second group, the studies include among others were Al-Jarrah \& Molyneuxa, 2003; Bader et al., 2007; Hussein, 2004; Mohamad et al., 2008; Akhter et al., 2011; Abduh et al., 2013; Wahid, 2016. Majority of these studies were using frontier approach, since it is superior compare to traditional analysis.

Ascarya, et al. (2008) explained that frontier approach is more superior because the use of this technical programme or statistics to reduce the effect from the difference of input price 
and other exogenous factors in influencing the observed performance. Frontier approach are divided into two kinds, there are: parametric approach and non-parametric approach. Stochastic Frontier Approuch (SFA), Thick Frontier Approuch (TFA) and Distribution Free Approach (DFA) are kinds of parametric approaches, while Data Envelopment Approach (DEA) and Free Disposable Hull (FDH) are kinds of non-parametric approaches (Syakir, 2004). Hadad, et al (2003) also stated that, eventually parametric and non parametric approaches are used; they will establish the same result if the analyzed samples are the same unit and using the same process productions. In economic theory, there are two kinds of efficiency; there are economic efficiency and technical efficiency. Economic efficiency is describing macro economy, while technical efficiency is describing micro economy. Technical efficiency measurement is only applied in one technical and operational relationship in process using of input into output (Hadad, et al., 2003).

Hadad, et al. (2003) explained that there are three approaches that are widely used in parametric and non parametric approaches to define the correlation of input and output in financial activities of financial institutions, namely asset approach, production approach, and intermediation approach. This research is using intermediation approach to consider the main function of bank as financial intermediation which is collecting fund from surplus unit and distribute it to deficit one. Hence, taking into account another basic feature of bank which is mainly doing the quality of asset transformation eventhough there is no common agreement to determin input and output variables.

However, the performance measurement by Islamic bank is still applying classic performance measurement which is heavily focused on financial aspects of financial intermediary institution, such as return on assets (ROA) and return on equity (ROE), as well as its technical aspects, such as operating costs over operating income (OCOI), non-performing financing (NPF) and financing to deposits ratio (FDR), including efficiency measures, such as technical efficiency and cost efficiency. Having different nature of values and variety of products, any efforts to conduct assessment and supervision between Islamic banks and conventional banks should be different.

Islamic banking that is different from conventional banking both in theory and practice, needs a shifting paradigm in term of their performance measurement which not only limited to the financial ratios (stakeholders oriented) (Yuwono, et al., 2004). Every single effort or process taken by Islamic bank to maximize output should also uphold Islamic values, so that maqashid sharia (maslahah-sharia objectives) would be authomatically achieved.Therefore some papers that try to compare between sharia with conventional bank only by seeing its financial ratio just become less precise.

Several efforts to present the performance evalution of Islamic banks have been done based on maqashid sharia. These studies include, among others, Mohammed et al., 2008; Muhammed and Taib, 2009; Kuppusamy, Saleha and Samudhram, 2010; Antonio et al., 2012; Bedoui and Mansour, 2013; Jazil and Syahruddin, 2013; Muayyad and Esya, 2016, and Saoqi, 2017. However, these studies were not explicitly addressing the issue of cost-saving strategies within the framework of efficiency measurement. Efficiency is a process of how firm utilizes their resources (inputs) to produce the desired products or services (outputs). It will indicate 
the success of the firm. If the firm gains a high level of efficiency, it indicates that the firm performs well in the operating condition and is able to manage all the resources. Eventually, this will lead to further developments such as improvement in the products and services, higher shareholder's value and higher economic growth if the funds are invested into more profitable ventures.

From the above literatures, it can be concluded that there are at least two current models of Islamic banking performance evaluation that have been done: first, the performance evaluation of Islamic banks within the framework of efficiency; Second, the performance evaluation of Islamic bank within the framework of maqashis al-syariah.

\section{Maqashid Sharia Index (MSI) Approach}

Ghazali (1991) said "anything that guarantees or safeguarding the preservation of the sharia objectives (maqashid sharia) is called maslahah and every matter that escape from it called mafsadah (damage)". There are five maqashid sharia that should be saguarded in every single transaction or activities (muamalah), namely faith, human self or life, intellect, posterity or lineage and wealth (al-kulliyyah al-khamsah), including Islamic bank practices. In a broader meaning, maqashid sharia is the ultimate goal of sharia which promoting welfare and benefit values (Jalb al-Mashalih) also eliminate misery (Dar al-Mafasid) (Al-Jauziyah, 1973, Yubi, 1998, Ibn Asyur, 2000, Al-Fasy, 1993). Therefore, performance evaluation of Islamic bank should cover the al-kulliyyah al-khamsah (maqashid sharia) to be considered as achieving mashalih or mashlahah.

The performance evaluation of Islamic bank which is different from conventional bank is because of different set of values and products between the parties. The most fundamental difference is related to the reference value (Islamic Worldview) for each financial institution. This fundamental difference will lead to the differences on formulation or creation of the product for both banking model including each performance evaluation model. Umar Chapra concluded that the differences in economic systems and other economic system rests on three main things: (1) Islamic Worldview (2) Purposes (3) Strategy or Policy (Chapra, 2005). Different worldview from the conventional will have an impact on objective formulation of Islamic bank. Different objective formulation also will have an impact to different strategical formulation process or evaluation model. Those value not only expressed in the form of fiqh legality of particular product, but more than that it should have broad impact on economic and social aspect as a consequences of efforts to achieve Maqashid syariah (Sanrego, 2010, Rosly, 2010). Every single effort or process taken by sharia bank to maximize output should also uphold Islamic values, so that maqashid sharia (mashlahah) would be authomatically achieved.

Hence, apart from having different set of values compare to the conventional one, there are some weakness appeared if Islamic Bank just focus in performance measurement from financial aspects. First, by using financial ratio as the main factors performance measurement, manager will act only for short term goals not long term. Second, by ignoring non-financial measurement aspect and fixed assets, it will establish missing view of manager, now and future. Third, financial performance is conditioned based on past performance, thus 
unable to take the company to reach continuable goals, only if the main focus from banking activity consists of benefit value, not only for shareholders but also to other interested user (Mohammed et al., 2008)

In order to make sure the performance of Islamic bank in line with the maqashid sharia, there were some studies put forwarded maqashid sharia as their framework of analysis. One of the studies is written by Mohammed et al (2008) with their maqashid sharia index (MSI). Maqasid Sharia Index is evaluation or performance measurement model of Islamic bank, which is complied with the goal and Islamic bank characteristics. MSI is developed from three main factors, there are: education, creating justice, and welfare achievement, which is stem from another view of maqashid sharia that are divided into three categories tahdzib al-fard (education for individuals), iqamah al-adl (justice), and maslahah (benefit/welfare) (Abu Zahrah, 1958). Three of these main factors are designed to formulte education program and training in order to increase moral value, so human resource of Islamic Banking are able to develop their skill and knowledge. Justice means that Islamic Bank has to ensure the honesty and justice in every transaction and business activity including products, all free interest activities. Islamic Banking has to develop investment project and social services to develop society welfare.

Using Sakaran method, Mohammed et al (2008) have extended to develop Islamic Banking performance measurement idea according to Maqasid Sharia framework Operationally, Sakaran method is able to explain the element which is measured through this research. It is obviously done by observing dimensions behavior which is described through explained concept. Those dimensions are translated into reduced elements and observable and measurable, then could form measurement indexes. According to Sakaran method, behaviors characteristic are measured and reduced into a concept, which is notated as (C). Concept is reduced into some dimensions, and then it will be easly observed and measured, and notated as (D). So, the dimensions are going to reduced back into some clearly measured elements, and notated as (E).

As already presented by Ali (2008) related to the example of Sakaran method, by describing human thirsty behavior. Thirsty behavior is concept $(C)$ in this method. In order to be able to measured, thirsty behavior could be observed through how often somebody drink water, and in this case called (D) dimension. In order to be clearly measured, dimension is reduced into some measured elements, such as measuring how many glass of water are consumed to eliminate the thirsty. This is called by behavior measurement based on character or current criteria in Sakaran method.

Having Sakaran method, the objectives of bank related to Maqashid Sharia framework include: individual education, creating justice, and achieving the welfare, are then explained operationally. Every single objective is translated as concept (C). So, by the current characteristic is reduced into some measured dimensions (D). This dimension is clearly reduced into some elements, and will be easly measured (E). 
Table 1. Performance Ratio Measurement

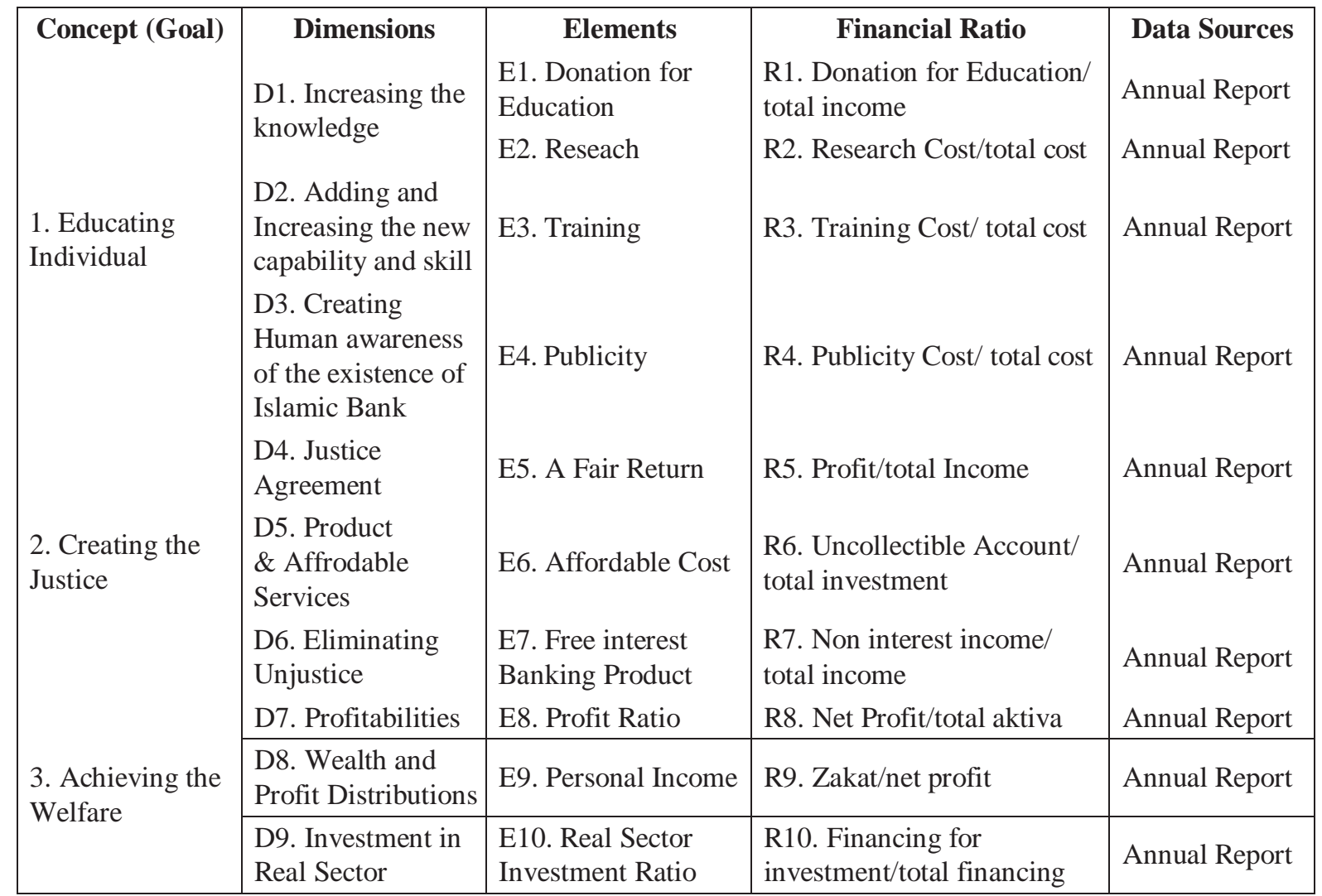

The ratios at table 1 are has been chosen since they fulfilled some criterias in this research:

1. The discussions about the objectives of Islamic bank are considered closer to the Islamic values and also could be reflected by these ratios. Both dimension and element are easily identified through these goals.

2. Some of literatures review which is inspecting the same problems is also using the same ratio in measurement, not only for Islamic bank but also for conventional bank. So it can be implemented in both institutions.

3. The data might be easy to collect, since the source of data is banking annual report.

4. The probability to measure the implementation maqasid sharia concept is more accurable by using these ratios.

The ratios which are presented in table 1 have been fulfilled maqashid sharia criteria. Those ratios descriptions and their correlations with maqasid sharia framework are:

a The first goal is individual education described by R1; Donation for Education/total income. R2; Research Cost/total cost. R3; Training Cost/ total cost. R4; Publicity Cost/ total cost. The interpretations of these four ratios are if ratio value is increasing, or if the allocations of the fund to fulfill these four indicators are increasing, then the goal achievement of maqashid sharia in Islamic Bank are also increasing.

b. The second goal is creating the justice, described by R5; Profit/total Incom. R6; Uncollectible Account/total investmen. R7; Non interest income/total income. The goal of creating the justice by Islamic Bank and Conventional Bank are better if R5 is getting lower. Means that 
if profit accepted by the bank are getting lower compared to total income, than the banking are valued highly implemented the goal of justice. As well as R6 is getting lower, then the goal of of justice in nasional banking is highly valued. Means if uncollactable financing in nasional banking is lower compared to total investment distributed, then the goal of justice is getting better, because reducing the gap of income distribution. In otherwise, the achievement of nasional banking is considered getting better if R7 are highly valued. Means that if non interest investment distributed by nasional banking are increasing compared to total investment, than the goal of justice is getting better according to maqashid sharia.

c. The third goal is achieving the welfare (maslahah), described trough R8; Net Profit/total aktiva. R9; Zakat/net profit. R10; Financing for investment/total financing. The goal of welfare would be achieved by nasional banking only if the value of R8, R9, \& R10 is increasing. Means that if net income, zakah and sector real investment are increasing, then support of nasional banking to create the maslahah are increasing.

\section{RESARCH METHODOLOGY}

\section{Efficiency Analysis}

Charnes, Cooper and Rhodes (1978) developed DEA by method of constant return to scale (CRS) and then developed by Banker, Charnes dan Cooper by method of variable return to scale (VRS) and finally popular with CCR (Charnes-Cooper-Rhodes) and BCC (BankerCharnes-Cooper) model. DEA is procedure, specifically formulated to measure relative efficiency in a bank which is using multiple input and output. Islamic Banking Efficiency measurement in this research is conducting by counting the ratio of output and input. Data Envelopment Analysis (DEA) will compute the period of Islamic Bank by using input $n$ to produce different output $\mathrm{m}$ (Miller and Noulas, 1996) in Komaryatin (2006). Efficiency in every period of Islamic Bank is computed by linier programming by maximizing weighted total output from period of Islamic Bank $s$. The restricted of total amount of weighted input must be equal to 1 to all bank, and total output reduced by weighted total input must be less or equal to 0. It means that all period of Islamic Bank is considered as well as or below the frontier performance reference (Insukindro, et al) in Komaryatin (2006).

Data Envelopment Analysis (DEA) will compute the value of hs, where hs is the efficiency score for each period of Islamic bank. Data Envelopment Analysis maximize the value of hs, where hs is sum multiplication between weight of output $i$ and total output $i$ in $s$ period of Islamic Bank.

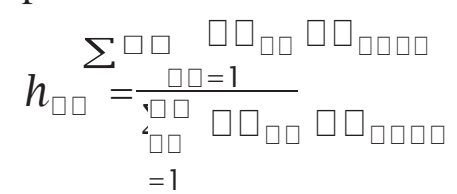

Where:

$h s=$ bank efficiency $\mathrm{s}$

$m$ = observed output bank $s$

$n=$ observed input bank $s$

$y i s=$ total output $i$ produced by bank $s$

$x j s=$ total input $j$ used bank $s$ 
$u i=$ weighted output $\mathrm{i}$ produced by bank $\mathrm{s}$

$v j=$ weighted input $j$ given by bank $s$ dan $i$ computed from 1 to $m$ and $j$ computed from 1 to $n$

The formulation above shows the use of one input variable and one output variable. Efficiency ratio $(h s)$ to be maximized by restricting as follows (Sutawijaya dan Lestari, 2009):

$\operatorname{Max} h_{\square \square}=$

Where $u_{i}$ and vj 0

From the formulation above, where $\mathrm{N}$ respresent total amount of bank in samples and $r$ is the type of bank sampled in this research. Inequality of first formula explained that the ratio of others DMU no more than 1, meanwhile second formula weigted non-negative (positive). Ratio value might be varying from 0 to 1 . The bank will be considered as efficient unit only if a ratio value nearly 1 or $100 \%$, otherwise if a ratio value nearly 0 shows bank efficiency is getting lower. In DEA, every bank could define their weight and ensure that the choosen weighting will result the best performance measurement (Sutawijaya and Lestari, 2009). Banxia Frontier Analyst 3 softwares is used to analyze technical efficiency in this research, and to measure stability on its efficiency, we used standard deviation approach, which is computed by formual as follows:

$$
s=\sqrt{\frac{n \sum_{i=1}^{n} x_{i}^{2}-\left(\sum_{i=1}^{n} x_{1}\right)^{2}}{n(n-1)}}
$$

Where:

$\mathrm{S}=$ Deviation Standard

$\mathrm{n}=$ Total year of analysis

$\mathrm{x}=$ Efficiency Score

\section{Maqashid Syariah Index (MSI) Analysis}

Nasional banking industry performance measurement used in this study is according to maqashid sharia framework. In this study, ratios used as already mentioned earlier in table 1 are conducted from literature review of Mohammed et al (2008). They verify the measurement used to some of Islamic scholar in Middle east and Malaysia, who are expert in both studies, Islamic banking studies and conventional banking studies. Confirmation is conducted in two steps. The first step is doing indepth interview to 12 experts of Islamic Banking studies, fiqh (Islamic law) and Islamic Economic studies related to performance measurement. The result of interview from 12 experts is they are agreed to the reliability of this developed instrument. Second step of this research, is verifying performance measurement which is developed by 16 experts in banking studies through questionnaire. All experts are expected to answer some questioness related to the weighted given by each ratio, in order to be easily measured, and reidentifying performance measurement component, wheter it is acceptable and compliance with banking situation. Mean weighting are given by the experts will be explained in table 2, as follows: 
Tabel 2. Mean Weighting for 3 goals and 10 elements given by Experts

\begin{tabular}{|c|c|c|c|}
\hline Goal & $\begin{array}{l}\text { Weighted Mean (scale } \\
100 \% \text { ) }\end{array}$ & Elements & $\begin{array}{l}\text { Weighted Mean (scale } \\
100 \% \text { ) }\end{array}$ \\
\hline \multirow{5}{*}{ O1. Education } & \multirow{5}{*}{30} & E1. Donation for Educations & 24 \\
\hline & & E2. Research & 27 \\
\hline & & E3. Training & 26 \\
\hline & & E4. Publicity & 23 \\
\hline & & TOTAL & 100 \\
\hline \multirow{4}{*}{ O2. Justice } & \multirow{4}{*}{41} & E5. Affrodable Return & 30 \\
\hline & & E6. Affordable price of product & 32 \\
\hline & & E7. Non interest product & 38 \\
\hline & & TOTAL & 100 \\
\hline \multirow{4}{*}{ O3. Welfare* } & \multirow{4}{*}{29} & E8. Profit Ratio & 33 \\
\hline & & E9. Income Distribution & 30 \\
\hline & & E10. Real Sector Investment Ratio & 37 \\
\hline & & TOTAL & 100 \\
\hline
\end{tabular}

*The welfare is include both bank and public interest

According to 10 ratios as already defined earlier, only 7 ratios are going to used in determining nasional banking performance, there are 4 ratios refer to the first sharia objectives (education), and the last 3 ratios refer to the $3^{\text {rd }}$ sharia objectives (welfare). Others 3 ratios refer to the $2^{\text {nd }}$ sharia objectives (justice) couldn't be applied in this research, because of the constraint of the sample data. There are some ratios used in this research are included:

a. Donation of education/total income $(\mathrm{R} 1,1)$

b. Research cost/total cost $(\mathrm{R} 1,2)$

c. Training cost/total cost $(\mathrm{R} 1,3)$

d. Publicity cost/ total cost $(\mathrm{R} 1,4)$

e. Net income/total aktiva $(\mathrm{R} 3,1)$

f. Zakat/net income $(\mathrm{R} 3,2)$

g. Investment for financing/total financing $(\mathrm{R} 3,3)$

This method is used to give the weighting, compute the variance and process the rank for the current data. This method is a decision making method for mutual attribute (MADM). Decision making must identify the main attribute and the value of intra attribute. The definition of attribute in this research is the goals to achieve maqashid sharia in nasional banking industry, and intra attribute is 10 elements and performance indicators as already mentioned in table 1. The respondent (decision maker) gives the weightingfor every single attributes and intra attributes in this research. Wheigthing for every attribute and intra attribute already presented in the earlier discussion and has been verified by some experts (see table 2). Performance data could be accessed through annual resport of six sample bank for the year of 2008-2012.

Decision maker will get the total score from each bank by multiplying scale rank for every attribute by evaluating exisiting respondent for every intra attributes and sum total score for product. Total overall computation from all performance indicators and performance ratio for every goal and for every bank describes maqashid sharia index. In this study, only two goals were used to achive maqasid sharia index. 
Having eficiency and maslahah analysis in one basket, therefore, the analysis framework of this study will be referring to the following figure 2 of quadrant:

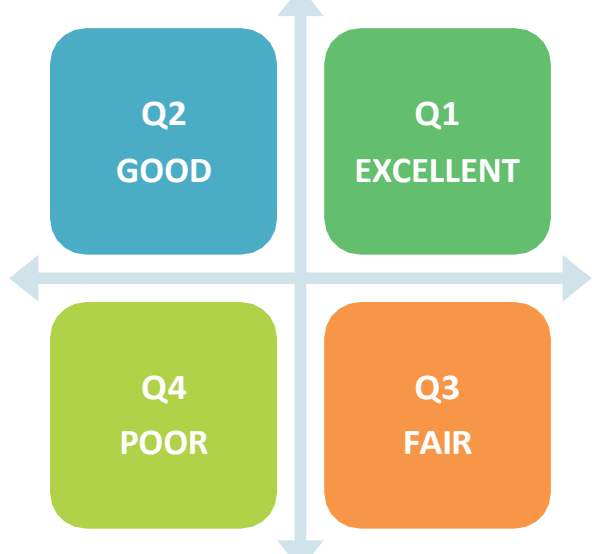

Figure 1 Maslahah-Efficiency Quadrant (MEQ)

\section{Where:}

Quadrant 1 (High Efficiency, High MSI) = Excellent

Quadrant 2 (High Efficiency, Low MSI) = Good

Quadrant 3 (Low Efficiency, High MSI) = Fair

Quadrant 4 (Low Efficiency, Low MSI) = Poor

\section{RESULT AND DISCUSSION}

In order to identify the efficiency score of Islamic Bank in Indonesia then we used Data Envelopment Analysis (DEA) method. Decision Making Unit (DMU) in this research is Sharia Business Unit Islamic Bank along the period 2014-2016. In obtaining the efficiency score from all DMU compared, we used Banxia Frontier Analyst 3 Software. DMU will be stated as efficience only if that current DMU can reach score value of 1 or $100 \%$, and otherwise, DMU will be stated as inefficience only if the score value is below 1 or $100 \%$. Here is the distribution efficiency score of Islamic Bank in Indonesia:

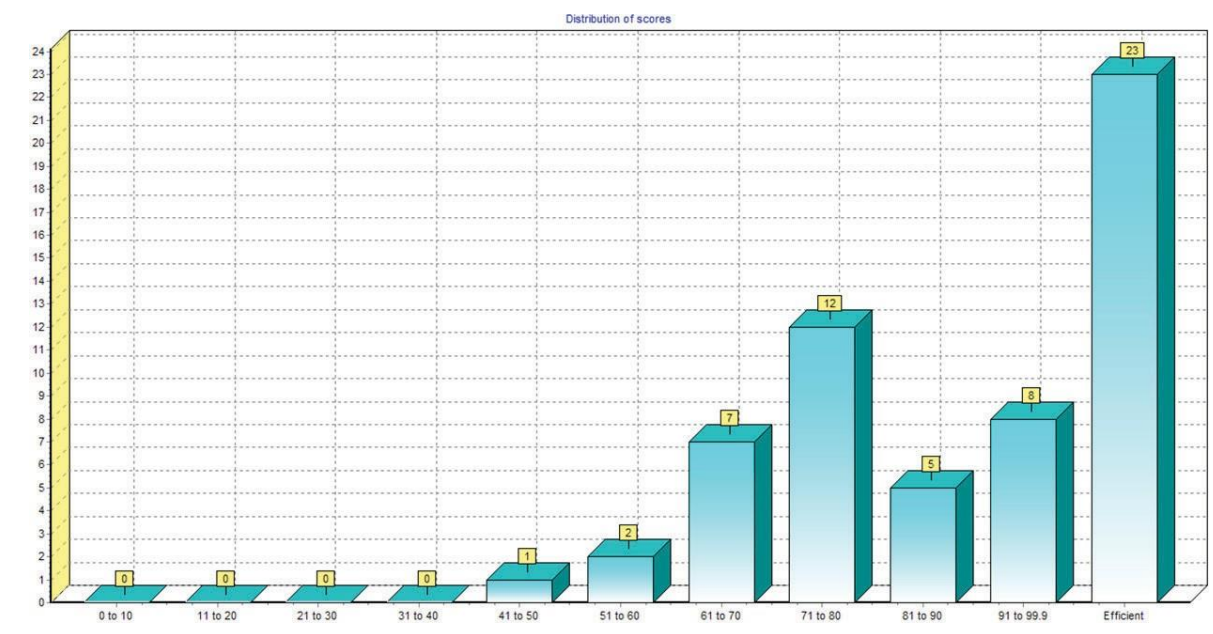

Figure 2: Distribution of Islamic Banking Efficiency in Indonesia 
According to the picture above, we can conclude that efficiency score of Islamic Bank Industry in Indonesia are varying. Perfect efficiency was reached by 23 DMUs. Whereas 8 DMUs of Islamic banks reach 91-99\% efficiency score. It means, just 39\% sharia units are fully efficient (23 DMUs from 58 DMUs). Upcoming result is to identify the mean value of efficiency and followed by Islamic Banking Industry performance measurement by Maqashid Shariah Index (MSI).

Table 3: Efficiency and MSI score of Islamic Bank in Indonesia, 2014-2016

\begin{tabular}{|r|l|r|r|r|r|r|}
\hline NO & EFFICIENCY & $\mathbf{2 0 1 4}$ & $\mathbf{2 0 1 5}$ & $\mathbf{2 0 1 6}$ & MEAN & MSI \\
\hline 1 & Danamon & 74.02 & 85.92 & 100 & 86.65 & 0.267 \\
\hline 2 & Permata & 100 & 100 & 100 & 100.00 & 0.244 \\
\hline 3 & Maybank & 100 & 100 & 100 & 100.00 & 0.211 \\
\hline 4 & CIMB & 89.54 & 93.35 & 100 & 94.30 & 0.257 \\
\hline 5 & OCBC NISP & 10.6 & 100 & 96.92 & 98.51 & 0.193 \\
\hline 6 & Sinarmas & 82.23 & 100 & 94.08 & 0.185 \\
\hline 7 & BTN & 98.73 & 96.8 & 100 & 98.51 & 0.277 \\
\hline 8 & DKI & 98.57 & 100 & 99.2 & 99.26 & 0.251 \\
\hline 9 & DIY & 79.4 & 71.94 & 93.85 & 81.73 & 0.219 \\
\hline 10 & Jateng & 64.34 & 72.76 & 70.96 & 69.35 & 0.210 \\
\hline 11 & Jatim & 45.92 & 53.83 & 65.29 & 55.01 & 0.238 \\
\hline 12 & Sumut & 100 & 76.6 & 79.2 & 85.27 & 0.246 \\
\hline 13 & Jambi & 100 & 89.73 & 94.87 & 0.271 \\
\hline 14 & Sumbar & & 100 & 100 & 100.00 & 0.199 \\
\hline 15 & Riau\&Kepri & 78.77 & 100 & 75.55 & 84.77 & 0.258 \\
\hline 16 & Kalsel & 70.1 & 58.81 & 67.8 & 65.57 & 0.274 \\
\hline 17 & Kalbar & 100 & 100 & 100 & 100.00 & 0.274 \\
\hline 18 & Kaltim & & 73.91 & 76.84 & 75.38 & 0.248 \\
\hline 19 & Sulselbar & 100 & 100 & 87.25 & 95.75 & 0.185 \\
\hline 20 & NTB & 71.6 & 76.57 & 65.34 & 71.17 & 0.160 \\
\hline & Mean & & & 87.51 & 0.233 \\
\hline
\end{tabular}

The table 3 above indivates that the biggest mean value of efficiency is achieved by Permata bank, Maybank sharia, Sumbar and Kalbar (100\%), and the lowest mean value of efficiency is achieved by Bank Jatim UUS (55\%). The highest performance is achieved by BTN Sharia with the MSI value 0.277, meanwhile the lowest performance is achieved by Sinarmas and Sulselbar Sharia with the MSI value 0.185.

\section{Islamic Banking Industry Performance within MEQ Framework}

According to this MEQ approach, Islamic Bank is grouped into (4) quadrants based on both efficiency score and maqashid shariah index (MSI), whether they are considered as high and low performance.

Quadrant 1 involves Islamic bank with both high efficiency and MSI performance, which will be considered as excellent. Quadrant 2 involves Islamic bank with high efficiency, 
but low MSI performance. Islamic bank within this quadrant is considered as a bank that capable to manage their resources and have enough efficiency rates, but have a less qualified MSI performance. Quadran 3 involves Islamic bank with low efficiency rates, but high MSI performance. The group of Islamic bank in this quadran could be considered as an Islamic bank, which doesn't notice the efficiency, but focus on the achievement of MSI performance. Last but not least is quadrant 4, which involves Islamic bank with both low efficiency rates and MSI performance. Islamic bank in this category is considered as poor bank since they have both efficiency rate and MSI performance in the low level.

The Figure 4 below describes Islamic Bank based on the computation of CRS efficiency score and performance score base on maqashid sharia index (MSI). This figure represents two categories, there are: efficiency score in $y$ axis, and the value of maqashid shariah index (MSI) in $x$ axis.

\section{Maslahah Efficiency Quadrant}

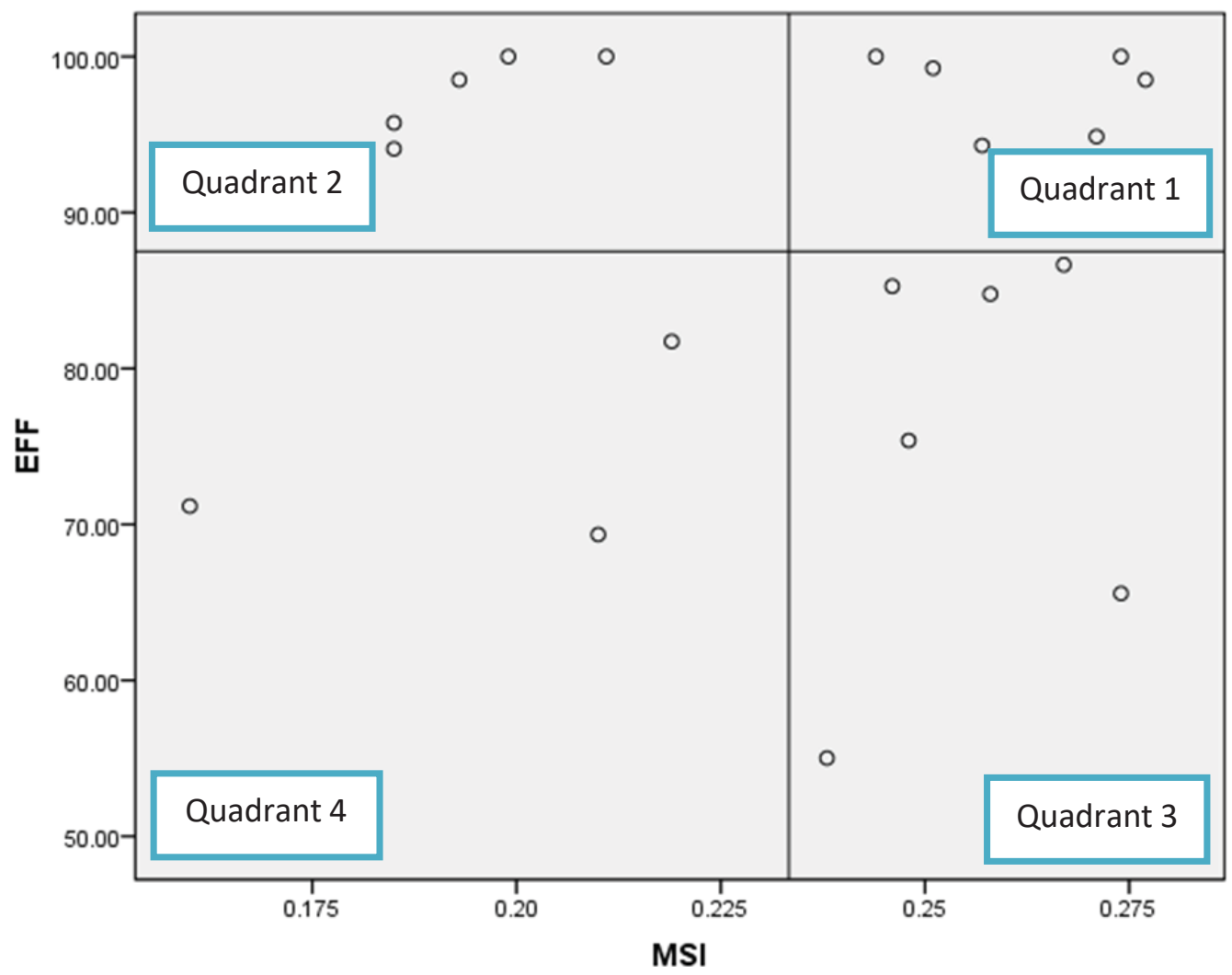

Figure 3: Maslahah-Efficiency Quadrant (MEQ) of Islamic Banking Industry

\section{Explanation:}

Quadrant 1 (High Efficiency, High MSI): Permata, CIMB, BTN, DKI, Jambi, Kalbar (Excellent) Quadrant 2 (High Efficiency, Low MSI): Maybank, NISP, Sinarmas, Sumbar, Sulselbar (Good) Quadrant 3 (Low Efficiency, High MSI): Danamon, Jatim, Sumut, Riau\&Kepri, Kalsel, Kaltim (Fair)

Quadrant 4 (Low Efficiency, Low MSI): DIY, Jateng, NTB (Poor) 
The above figure 3 indicate that within 2014-2016, there are six Islamic banks in the $1^{\text {st }}$ quadrant, five of Islamic banks in the $2^{\text {nd }}$ quadrant, six Islamic banks in the $3^{\text {rd }}$ quadrant, and three Islamic banks in the $4^{\text {th }}$ quadrant.

In the $1^{\text {st }}$ quadrant is Islamic bank with both high efficiency and high MSI performance. Islamic bank within the $1^{\text {st }}$ quadrant and considered as an excellent bank are Permata, CIMB, BTN, DKI, Jambi, and Kalbar. Having this value, it can be concluded that all of them are the most successful bank in managing their business and hence both of these banks have a great integrity to implement maqashid sharia as Islamic Bank in Indonesia. In other words, having high score both of efficiency rate and MSI performance lead to these six banks become the best bank in Indonesia.

The $2^{\text {nd }}$ quadrant is Islamic bank with high efficiency, but low MSI performance. Islamic bank within the $2^{\text {nd }}$ quadrant and considered as a good bank are Maybank, NISP, Sinarmas, Sumbar, Sulselbar. Islamic bank within this quadrant are considered as a good Islamic bank with high level of efficiency but low performance of MSI. From the efficiency framework, it could be concluded that these five banks have a sound capability to optimize financial resources to be well distributed. Eventhough, the performance achieved has not maximal yet, especially the performance related to sharia performance which measured by maqashid syariah index. The strategies conducted are to enhance bank performance and not only viewed from profit earning, but also from others factors MSI index.

The $3^{\text {nd }}$ quadrant is Islamic bank with low level of efficiency and high MSI performance. Islamic bank within this quadrant and considered as a fair bank are Danamon, Jatim, Sumut, Riau\&Kepri, Kalsel, and Kaltim shariah. All of these Islamic banks are considered as fair Islamic bank with low level of efficiency but high MSI performance. Within maqashid sharia framework, these six banks have been successful to achieve a high MSI performance because of their effort to comply some certain parameter of maqashid sharia, such as justice, welfare and education. However, since they haven't been achieving a high level of efficieny yet, therefore they urged to have more good management related to financial resources.

The last quadrant (the $4^{\text {th }}$ ) is for Islamic bank with both low efficiency and MSI performance. Islamic bank within this quadrant and considered as a poor are DIY, Jateng, and NTB. Having both low level of efficiency and MSI indicates that these bank are fail to manage and maximize their potention, particulalry within the issue financial aspect. Hence, these banks also unable to ascertain their sharia compliance performance. Therefore, it urged for these bank to have sufficient and comprehensive evaluation related to Islamic banking management as well as their commitment to sharia compliance issue.

\section{CONCLUSION AND RECOMMENDATION}

There were major concerns related to the practice of Islamic financial institution (IFI), particularly Islamic bank, to have a "better" evaluation measurement the way they are doing business. The performance evaluation of Islamic bank which is different from conventional bank carried out because of different set of values and products between the parties. The most fundamental difference is related to the reference value (Islamic Worldview) for each financial institution. This fundamental difference will lead to the differences on formulation or creation 
of the product for both banking model including each performance evaluation model. It is therefore, this paper has initiated the maslahah-efficiency quadrant (MEQ) approach which trying to have efficiency and maqashid sharia as a framework of analysis.

The MEQ approach indicates that Islamic bank within the $1^{\text {st }}$ quadrant and considered as an excellent bank are Permata, CIMB, BTN, DKI, Jambi, and Kalbar. It can be concluded that all of them are the most successful bank in managing their business and hence both of these banks have a great integrity to implement maqashid sharia as Islamic Bank in Indonesia. In other words, having high score both of efficiency rate and MSI performance lead to these six banks become the best sharia business units in Indonesia.

There is a challenge for future research to employ other method to have a comparison result within the efficiency framework with an updated data. Hence, the result in this current study might be changed accordingly subject to the future development of maqashid sharia concept.

\section{REFERENCES}

Abduh, M., Hasan, S., Pananjung, A. (2013), Efficiency and performance of Islamic Banks in Bangladesh. Journal of Islamic Banking and Finance, 30(2), 94-106.

Abu Zahrah, Muhammad. (1958). Ushul Al-Fiqh. Darul Fikri al-Araby.

Akhter, W., Raza, A., Akram, M. (2011), Efficiency and performance of Islamic Banking: The case of Pakistan. Far East Journal of Psychology and Business, 2(2), 54-71.

Ali, Mahbubi. (2010). "Analisis Efisiensi Baitul Maal wat Tamwil dengan Pendekatan Two Stages DEA (Studi Kasus Kantor Cabang BMT MMU dan BMT UGT Sidogiri). Tazkia Islamic Finance and Business Review. Vol 5 No 2, 2010.

Al-Jarrah, I., \&Molyneuxa, P. (2003). Cost efficiency, scale elasticity and scale economies in Arabian banking. Financial Development in Arab Countries, 25

Antonio, M. Syafii (2000), Bank Syariah: Dari Teori Ke Praktek, Jakarta: Gema Insani Press Antonio, Sanrego dan Taufiq. (2012). An Analysis of Islamic Banking Performance: Maqasid Index Implementation in Indonesia and Jordania. Jurnal of Islamic Finance IIUM, Vol. 1 No. 1 (2012)012-029

Ascarya, Yumanita, D. dan Guruh S. R. (2008). Analisis Efisiensi Perbankan Konvensional dan Perbankan Syariah di Indonesia dengan Data Envelopment Analysis (DEA). Paper in the book of Current Issues Lembaga Keuangan Syariah Tahun 2009, TIM IAEI, Jakarta: Kencana Prenada Media Group

Ascarya \& Yumanita, D. (2007). Comparing the Efficiency of Islamic Banks in Malaysia and Indonesia. Paper presented at IIUM International Conference on Islamic Banking and Finance (IICiBF): Research and Developement between Ideals and Realities. IIUM Kuala Lumpur, 23-25 April.

Bader, M. K. I., Mohamad, S., Ariff, M., \& Hassan, T. (2007). Cost Revenue, and Profit Efficiency of Conventional versus Islamic Banks: Financial Ratios Approach. Review of Islamic Economics, 11, 89-106 
Bedoui, H. and Mansour, W. (2013). Islamic banks performance and Maqasid al-Shari'ah. Paper presented to the 9th Asia-Pacific Economic Association Conference, Osaka, Japan, July 27-28.

Brown, K., \&Skully, M. (2004). Islamic banks: a cross-country study of cost efficiency performance.

Chapra, M. Umar. (2005). Islam dan Pembangunan Ekonomi. Ikhwan Abidin, Translator. Depok: Gema Insani. from: Islam and Economic Development.

Charnes, A., Cooper, W.W., and Rhodes, E. (1978). Measuring the Efficiency of Decision Making Units. European Journal of Operation Research, Vol. 2, No. 6, pp. 429-44

Coelli.T.I, Rao, D.S.P. and Battese, G.E. (1998). Introduction to Efficiency and Productivity Analysis, Kluwer Academic Publisher, Boston.

Coelli, T.J, Rao, D.S.P., Prasada Rao, Christoper J. O’Donnel and G.E. Battese. (2005). Introduction to Efficiency and Productivity Analysis, (Second Edition), Kluwer Academic Publishers, Boston.

Cooper, William W., Seiford, Lawrence M., and Tone, Koru. (1999). A Comprehensive Text with Models, Application, References and DEA-Solver Software, Kluwer Academic Publisher, Boston USA.

Cooper, et al. (2002). Data Envelopment Analysis. Kluwer Academic Publisher, USA. Cooper, William W, Lawrance M. Seiford and Joe Zhu. (2010). Handbook on Data Envelopment Analysis. London: Springer.

Farrell, M.L. (1957). The Measurement of Productive Efficiency. Journal of The Royal Statistical Society, 120, p.253-281.

Fasy, 'Allal. (1993). Maqashid Asy-Syariah Al-Islamiyyah Wa Makarimuha (5th edition). Darul Garb Al-Islamy.

Ghazali, Abu Hamid. (1991). Al-Mushtashfa Min Ilmil Ushul (1st edition). Editor: Muhammad Abdus Salam. Beirut: Darul Kutub al-Ilmiyyah.

Freixas, Xavier and Rochet, Jean-Charles (2008). Microeconomics of Banking 2nd Edition, The MIT Press, Cambridge, Massachusetts, London, England.

Hadad, M., Wimboh, S., Dhaniel, I., \& Eugenia, M. (2003). Analisis Efisiensi Industri Perbankan Indonesia: Penggunaan Metode Nonparametrik Data Envelopment Analysis (DEA). Jakarta: Direktorat Penelitian dan Pengaturan Perbankan. Bank Indonesia

Hassan, M. K. (2006). The X-efficiency in Islamic banks. Islamic Economic Studies, 13(2), 49-78.

Hussein, K. A. (2004). Banking Efficiency in Bahrain: Islamic vs. Conventional Banks: Islamic Development Bank, Islamic Research and Training Institute.

Ibnu 'Asyur, Muhammad Thahir. (2000). Maqashid Asy-Syariah Al-Islamiyyah. Yordania: Darun Nafais.

Islamic Banker Association. 2018. Global Islamic Finance Report 2018. 
Jauziyah, Ibnu Qayyim. (1973). I'lamul Muwaqqi'in 'an Rabbil Alamin. Editor: Thaha Abdur Rauf Sa'd. Beirut: Darul Jail

Jazil, T \& Syahruddin. (2013). The Performance Measurer of Selected Malaysian and Indonesian Islamic Banks based on the Maqasid al-Shari'ah Approach, Vol, 7 No. 2.

Komaryatin, N. (2006). Analisis Efisiensi Teknis Industri BPR di Eks Karesidenan Pati.

Semarang: Pasca Sarjana Universitas Diponegoro

Kuppusamy, M., Saleha, A. S., \& Samudhram, A. (2010). Measurement of Islamic Banks Performance Using a Shariah Conformity and Profitablity Model. Jurnal Review of Islamic Economics, Vol. 13, No. 2, h. 35-48.

Mohamad, S., Hassan, T., \& Bader, M. K. I. (2008). Efficiency of conventional versus Islamic Banks: international evidence using the Stochastic Frontier Approach (SFA). Journal of Islamic Economics, Banking and Finance, 4(2), 107-130.

Mohammed, M. O. Dzuljastri, A.R \& Taib, F. Md. (2008). The Performance Measures of Islamic Banking Based on the Maqashid Framework. Paper of IIUM International Accounting Conference (INTAC IV) held at Putra Jaya Marroitt.

Mohammed, M. O., \& Taib, F. Md. (2009). Testing The Performance Meaasured Based on Maqashid al-Shariah (PMMS) Model on 24 Selected Islamic and Conventional Banks. Malasyia: IIUM.

Muayyad, D. M. \& Esya, L. (2016). Implementation of Maqasid Sharia in Islamic Financial Institution in Indonesia. International Scholarly and Scientific Research \& Innovation. Vol. 3, No. 9.

Nopirin. (1997). Pengantar Ilmu Ekonomi Makro dan Mikro. Yogyakarta: BPFE

Otoritas Jasa Keuangan. (2018). Statistik Perbankan Syariah Indonesia.

Omar dan Dzuljastri. (2008). The Performance Measures of Islamic Banking Based on the Maqasid Framework, IIUM INTAC IV best paper.

Rosly, Saiful Azhar. (2010). Shariah Parameters Reconsidered. International Journal of Islamic and Middle Eastern Finance and Management Vol. 3 No. 2, h.137

Sanrego, Y. D. (2010). Maqashid Indeks Untuk Bank Syariah. SHARING Inspirator Ekonomi \& Bisnis Syariah Edisi 41 Thn IV-Mei.

Saoqi, A. A. Y. (2017). Analyzing the Performance of Islamic Banking in Indonesia and Malaysia: Maqasid Index Approach. Jurnal Ekonomi Islam. Vol. 8, No. 1

Sufian, F. (2006). The Efficiency of Islamic Banking Industry in Malaysia: Foreign Versus Domestic Banks, Paper, INCEIF Colloquium, Malaysia, April.

Suleiman, N. M. (2000). Corporate governance in Islamic banks. Working paper, http://www. lib.bke.hu/gt/2000-3/nmsuleiman.pdf

Sutawijaya, A., \& Etty P. L. (2009). Efisiensi teknik Perbankan Indonesia pascakrisis ekonomi : Sebuah studi empiris penerapan model DEA. Jurnal Ekonomi Pembangunan, Vol. 10, No. 1, Juni, pp. 49-67. 
Syakir, A. K. (2004). Mengukur Efisiensi Intermediasi Sebelas Bank Terbesar Indonesia Dengan Pendekatan Data Envelopment Analysi (DEA). Jurnal Bisnis Strategi. Vol.13. Hal. 126-139, Semarang.

Wahid, M. A. (2016). Comparing the Efficiency of Islamic and Coventional Banks Based on the Evidence from Malaysia. JMFIR Vol, 13. No. 1 June.

Yubi, Muhammad Saad. (1998). Maqashid asy-Syariah al-Islamiyah Wa 'Alaqatuha Bil Adillah Asy-Syar'iyyah (Cet.1). KSA: Darul Hijrah Lin Nasyr Wat Tauzi'.

Yudistira, D. (2003). Efficiency in Islamic banking: an empirical analysis of 18 banks. Unpublished Paper, Leicestershire: Department of Economics, Loughborough University, UK.

Yuwono, Sony, et al. (2004). Petunjuk Praktis Penyusunan Balance Scorecard Menuju Organisasi yang Berfokus pada Strategi. Jakarta: PT Gramedia Pustaka Utama. 